dr inż. Marek Sobaś

Instytut Pojazdów Szynowych „,TABOR”

\title{
Wyniki badań wytrzymałościowych trójkatów hamulcowych $w$ apspekcie statystycznym
}

\begin{abstract}
W artykule przedstawiono stanowiskowe badania wytrzymatościowe trójkata hamulcowego wózków wagonów towarowych. Przedstawiono aktualnie obowiazujace kryteria. Zaprezentowano przebieg badań, wyniki badań stanowiskowych oraz obróbkę statystycznq wyników przeprowadzonych pomiarów.
\end{abstract}

\section{WSTĘP}

Trójkąty hamulcowe są podzespołami hamulcowych przekładni mechanicznych wózków wagonów towarowych, wyposażonych w klocki cierne. W skład klocków wchodzą obsady klocków hamulcowych oraz wstawki. Wstawki klocków hamulcowych jako element cierny były wykonywane tradycyjnie z żeliwa P10 wg karty UIC 832 [4], a obecnie wytwarza się wstawki kompozytowe [7,8]. Obciążenie trójkątów hamulcowych wynika z parametrów pojazdu i wózka, do których można zaliczyć:

- maksymalny nacisk zestawu kołowego na tor,

- maksymalną prędkość pojazdu,

- geometrię przekładni hamulcowej,

- przełożenie przekładni hamulcowej,

- rodzaj użytych wstawek hamulcowych.
W przypadku standardowych wózków wagonów towarowych rozróżnia się trzy rodzaje trójkątów hamulcowych: o umownej nośności $45 \mathrm{kN}$, do ruchu „S” o umownej nośności $60 \mathrm{kN}$ oraz do ruchu „SS” o umownej nośności 120 kN. Trójkąty dla wózków standardowych mogą posiadać odmienne konstrukcje, jednak pod warunkiem zamienności, czyli spełniania wymagań wymiarowych wg karty UIC 543 [3]. Trójkąty hamulcowe muszą również spełniać wymagania wytrzymałościowe, które są sprawdzane na stanowisku do badań wytrzymałościowych. Zgodnie z kartą UIC 833 [5] stanowiskowe badania wytrzymałości trójkątów hamulcowych należy wykonać w następujących przypadkach:

- nowej konstrukcji trójkąta hamulcowego,

- wprowadzenia zmian konstrukcyjnych do już eksploatowanej konstrukcji,

- zmiany technologii wykonania,

- zmiany wytwórcy lub producenta.
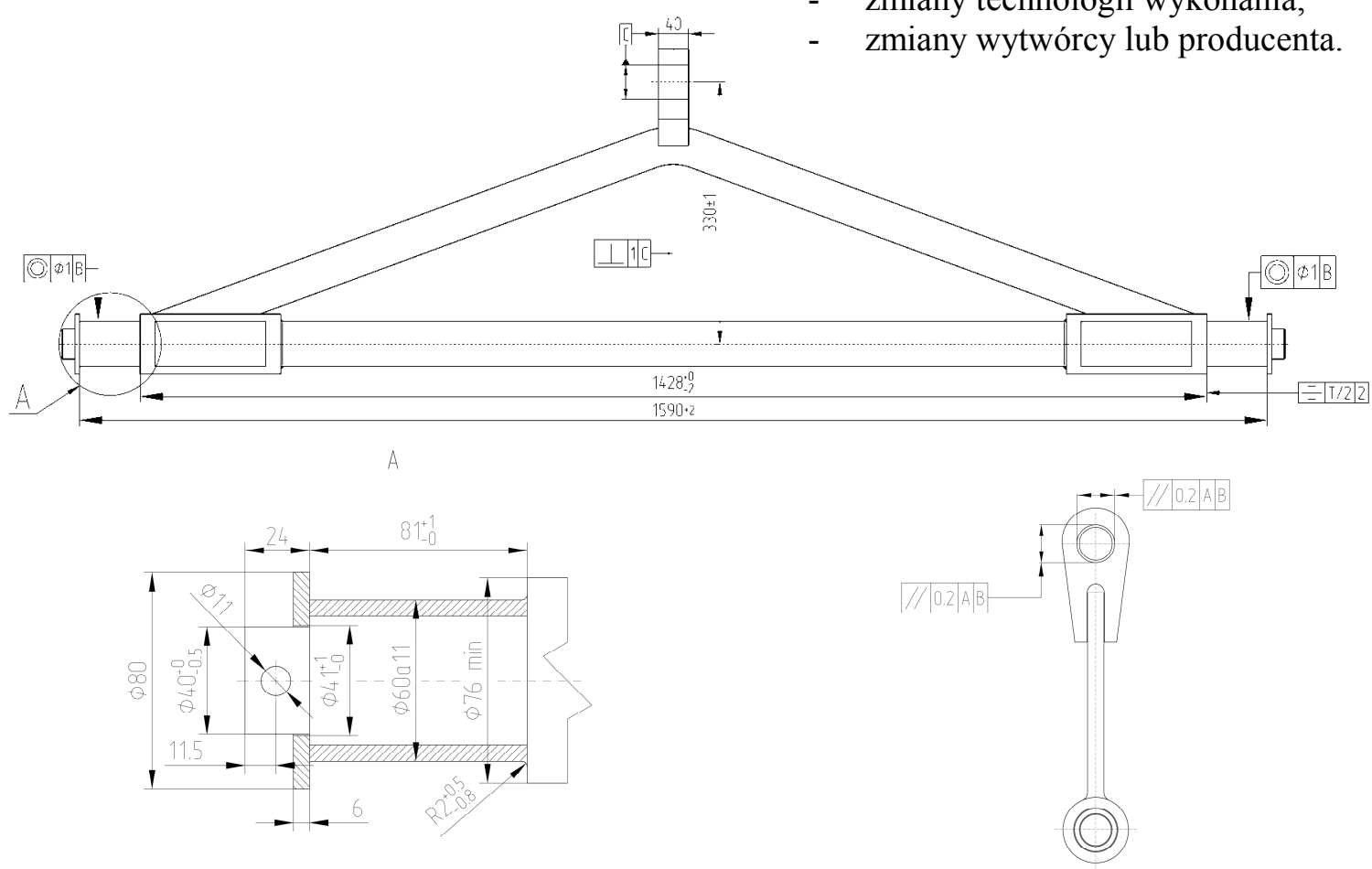

Rys. 1. Wymiary wraz z przynależnymi odchyłkami kształtu i położenia, które muszą spełniać trójkąty hamulcowe do wagonów towarowych 


\section{KRYTERIA WYTRZYMALOŚCI TRÓJ- KĄTA HAMULCOWEGO}

Kryteria wytrzymałości statycznej i zmęczeniowej dla trójkątów hamulcowych są przedstawione w karcie UIC 833 [5].

Trójkąty hamulcowe niezależnie od rodzaju ruchu (,S” lub „SS”) muszą być przystosowane do przeniesienia obciążeń wynikających $\mathrm{z}$ procesu hamowania nagłego, które jest realizowane podczas eksploatacji wagonów towarowych. jące obciążenia:

Konstrukcja trójkąta musi przenieść następu-

$>$ statyczne: nominalne oraz nadzwyczajne,

$>$ zmęczeniowe.

W ramach reżimów hamulcowych ,S” oraz „SS” powstały dwie odmiany trójkątów hamulcowych. Zasadnicza różnica pomiędzy dwoma odmianami trójkątów hamulcowych wynika z konieczności przeniesienia dwukrotnie większych sił przez trójkąty, które są przystosowane do ruchu „SS”. Obydwa trójkąty hamulcowe muszą jednak spełniać wymagania zamienności zgodnie z kartą UIC 543 [3] oraz tablicą 12. przepisów TSI [9]. Wymiary wraz z tolerancjami oraz odchyłkami kształtu i położenia, które muszą być zachowane aby zapewnić wymienność części są przedstawione na rys. 1 .

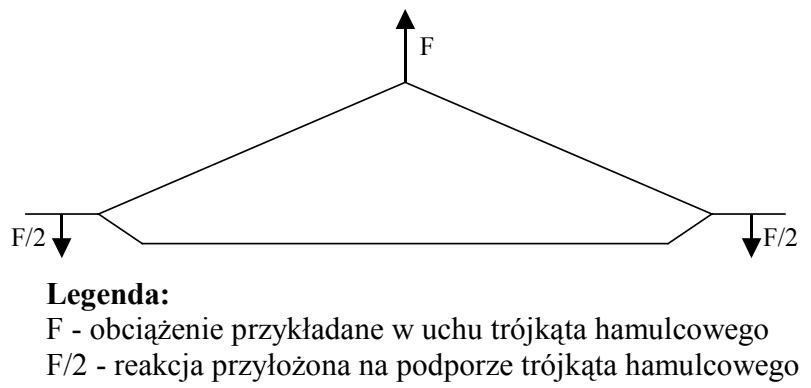

Rys. 2. Schemat obciążeń trójkąta hamulcowego siłami poziomymi

Wartości obciążeń statycznych i zmęczeniowych są rzestawione w tabeli 1.
Dla zadanych obciążeń statycznych obowiązują dopuszczalne strzałki ugięcia, które są przedstawione w tabeli 2.

Statyczne badania wytrzymałościowe trójkątów hamulcowych należy przeprowadzić zgodnie $\mathrm{z}$ PN-91/K-88176 [6] oraz kartą UIC 833 [5]. Przebieg statycznych badań wytrzymałościowych jest przedstawiony na rys. 3 .

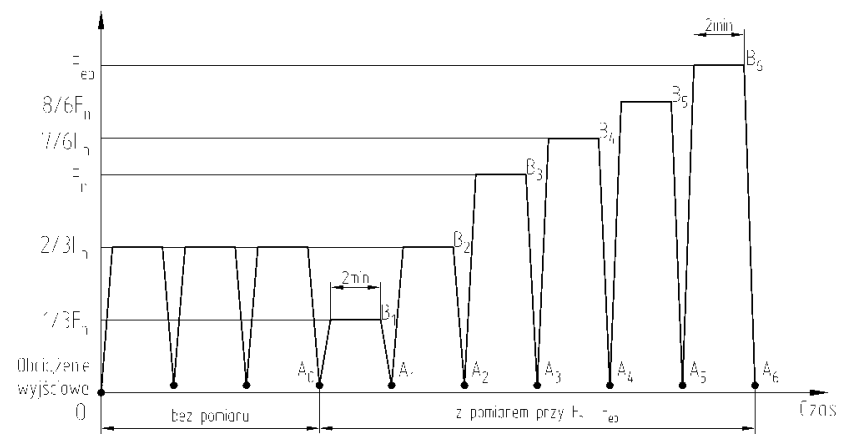

Rys. 3. Przebieg statycznych badań wytrzymałościowych wg PN91/K-88176 [6] oraz karty UIC 833 [5]

Badany trójkąt hamulcowy należy umieścić w urządzeniu pomiarowym i poddać przez 2 minuty trzykrotnie obciążeniu wstępnemu równemu $2 / 3$ obciążenia nominalnego $F_{n} w g$ tabeli 1 . Każdorazowo po 2 minutach obciążenia wstępnego jego wartość powinna być obniżona do wartości obciążenia wyjściowego wg tabeli 1 . Po trzykrotnym obciążeniu trójkąta hamulcowego obciążeniem wstępnym należy zmierzyć odległość $\mathrm{H}$, a następnie poddać trójkąt obciążeniom: $1 / 3 F_{n}, 2 / 3 F_{n}, F_{n}, 7 / 6 F_{n}, 8 / 6 F_{n}$ oraz $F_{e p}$. Czas działania każdego obciążenia wynosi 2 minuty, przy czym przyłożenie poszczególnych obciążeń powinno być poprzedzone powrotem do obciążenia wyjściowego wg rys. 4.

W czasie badania należy wykonać pomiary $\mathrm{H}$ dla każdej wartości obciążenia wstępnego i wyjściowego, a następnie określić:

Zestawienie obciążeń, działających na trójkąt hamulcowy, przystosowany do ruchu „S” zgodnie z kartą UIC 833 [5] oraz PN-91/K-88176 [6]

Tabela 1

\begin{tabular}{|c|c|c|c|c|}
\hline L.p. & $\begin{array}{c}\text { Obciążenie wyjściowe } \\
{[\mathbf{k N}]}\end{array}$ & $\begin{array}{c}\text { Obciążenie nominal- } \\
\text { ne } \mathbf{F}_{\mathbf{n}}[\mathbf{k N}]\end{array}$ & $\begin{array}{c}\text { Obciążenie próbne } \\
\mathbf{F}_{\text {ep }}[\mathbf{k N}]\end{array}$ & $\begin{array}{c}\text { Obciążenie przy } \\
\text { próbie wytrzymałości } \\
\text { na zmęczenie }[\mathbf{k N}]\end{array}$ \\
\hline 1. & 5 & 60 & 90 & $10 \div 60$ \\
\hline
\end{tabular}

Zestawienie dopuszczalnych odkształceń dla sił nominalnych i próbnych, działających na trójkąt hamulcowy do ruchu „S" zgodnie z karta UIC 833 [5] oraz PN-91/K-88176 [6]

Tabela2

\begin{tabular}{|c|c|c|c|}
\hline Rodzaj odksztalcenia & $\begin{array}{c}\text { Odksztalcenie } \\
{[\mathbf{m m}]}\end{array}$ & $\begin{array}{c}\text { Obciążenie } \\
\text { nominalne } \mathbf{F}_{\mathbf{n}}[\mathbf{k N}]\end{array}$ & $\begin{array}{c}\text { Obciążenie próbne } \\
\mathbf{F}_{\mathbf{e p}}[\mathbf{k N}]\end{array}$ \\
\hline sprężyste & 2 & 60 & 0 \\
\hline trwałe & 0,1 & 60 & 0 \\
\hline sprężyste & 3 & 0 & 90 \\
\hline trwałe & 0,5 & 0 & 90 \\
\hline
\end{tabular}


odkształcenie sprężyste wywołane obciążeniem nominalnym $\mathrm{F}_{\mathrm{n}}$, równe różnicy wymiarów $\mathrm{H} \mathrm{w}$ punkcie $\mathrm{B}_{3}$ i $\mathrm{A}_{3}$,

$>$ odkształcenie trwałe wywołane obciążeniem nominalnym $F_{n}$, równe różnicy wymiarów $\mathrm{H} \mathrm{w}$ punkcie $\mathrm{A}_{3}$ i $\mathrm{A}_{0}$,

$>$ odkształcenie sprężyste wywołane obciążeniem próbnym $F_{n}$, równe różnicy wymiarów $H$ w punkcie $\mathrm{B}_{6} \mathrm{i}_{6}$,

$>$ odkształcenie trwałe, wywołanie obciążeniem próbnym $\mathrm{F}_{\mathrm{ep}}$ równe różnicy wymiarów $\mathrm{H}$ w punkcie $\mathrm{A}_{6}$ i $\mathrm{A}_{0}$.

Wymiar $\mathrm{H}$ jest przedstawiony na rys.4.

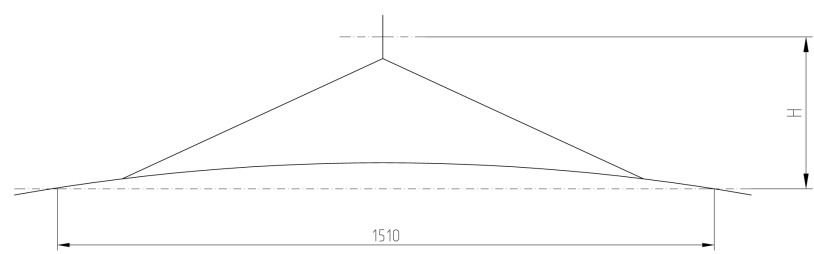

Rys.4. Wymiar H między osią ucha i wspólną osią czopów trójkąta hamulcowego przechodzącą przez ich środki

W celu dopuszczenia konstrukcji trójkąta hamulcowego do eksploatacji przeprowadza się badania statyczne i zmęczeniowe na stanowisku badawczym. Trójkąty hamulcowe poddaje się badaniom statycznym, przy czym bada się odkształcenia sprężyste i trwałe na 8 sztukach prototypowych trójkątów hamulcowych. Przykłady stanowisk badawczych do badań statycznych są przedstawione na rys. $5 \div 8$ (warianty I $\div$ IV).

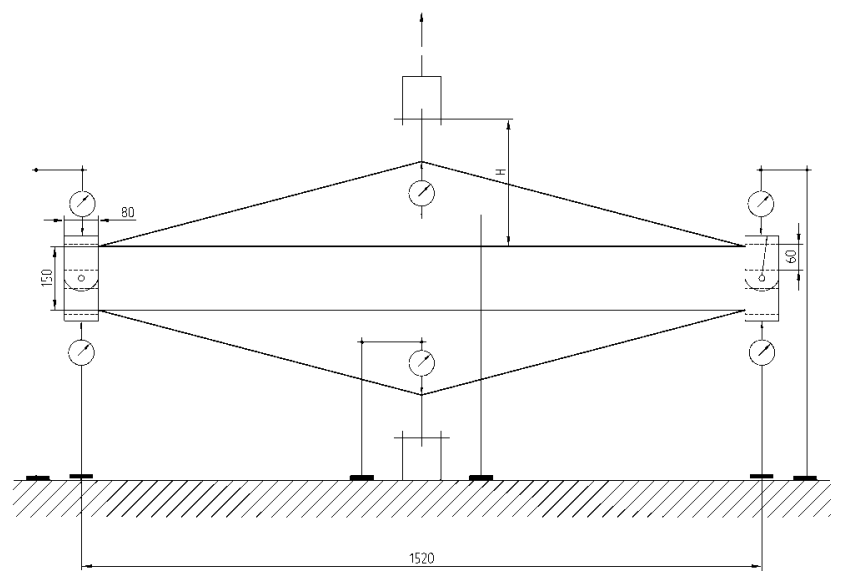

Rys.5. Przykład stanowiska do badań statycznych trójkąta hamulcowego. Wariant I wg karty UIC 833 [5]

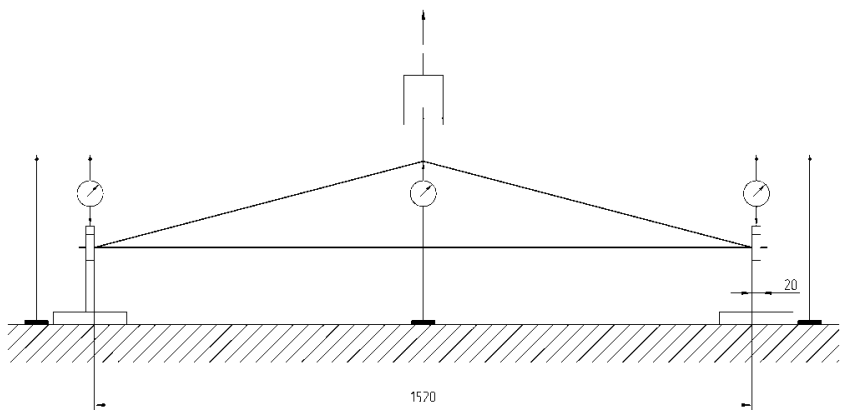

Rys.6. Przykład stanowiska do badań statycznych trójkąta hamulcowego. Wariant II wg karty UIC 833 [5]

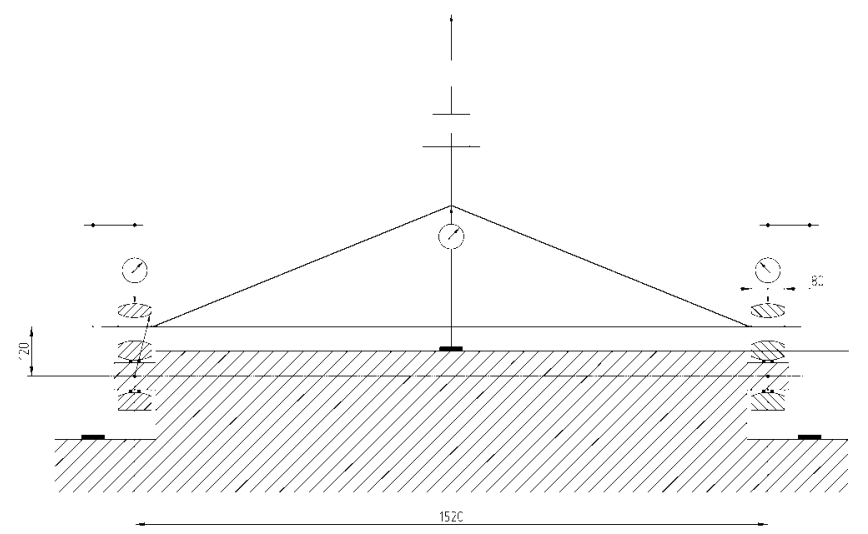

Rys.7. Przykład stanowiska do badań statycznych trójkąta hamulcowego. Wariant III wg karty UIC 833 [5]

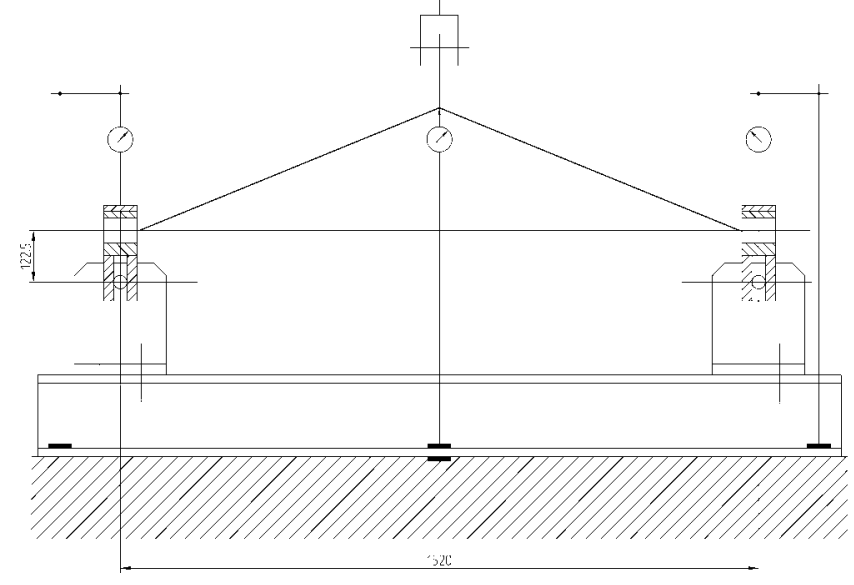

Rys.8. Przykład stanowiska do badań statycznych trójkąta hamulcowego. Wariant IV wg karty UIC 833 [5]

$\mathrm{Na}$ dwóch dodatkowych trójkątach przeprowadza się stanowiskowe badania zmęczeniowe $\mathrm{z}$ częstotliwością przykładania obciążeń tętniących $\mathrm{w}$ zakresie $10 \div 60 \mathrm{kN}$, wynoszącą $2 \div 16 \mathrm{~Hz}$. Próby zmęczeniowe uznaje się za pozytywne, jeśli nie wystapi żadne widoczne uszkodzenie trwałe ani też pękniecie, powodujące utratę nośności konstrukcji. Badania zmęczeniowe przeprowadza się na stanowisku stacjonarnym, które jest wyposażone $\mathrm{w}$ urządzenia do rejestracji częstotliwości oraz mogących mierzyć wartość chwilową przyłożonych obciążeń.

Podsumowując, kryteria wytrzymałościowe konstrukcji trójkąta hamulcowego sprowadzają się do:

zachowania dopuszczalnych strzałek ugięcia pod zadanymi obciążeniami $\mathrm{F}_{\mathrm{n}}$ i $\mathrm{F}_{\mathrm{p}}$,

$>$ zachowania dopuszczalnych odkształceń trwałych pod obciazżeniami $\mathrm{F}_{\mathrm{n}} \mathrm{i} \mathrm{F}_{\mathrm{p}}$,

$>$ zachowania takiego poziomu naprężeń $\mathrm{w}$ konstrukcji (wytężenia materiału), które pozwala na przejście cyklu zmęczeniowego. 
Ograniczenie dopuszczalnych strzałek ugięcia dla trójkątów hamulcowych wynika ze zdolności regulacyjnej nastawiacza klocków hamulcowych, który jest zainstalowany w układzie hamulcowym wagonu towarowego i który jest odpowiedzialny za utrzymanie odpowiedniego skoku tłoka cylindra hamulcowego w trakcie eksploatacji.

Zdolność regulacyjna nastawiacza sprowadza się do kompensacji:

$>$ zużycia powierzchni tocznej koła,

$>$ zużycia wstawek klocków hamulcowych,

$>$ ugięć poszczególnych elementów (dźwigni, cięgien i trójkątów hamulcowych) przekładni hamulcowej.

W przypadku zakwalifikowania danej konstrukcji trójkąta hamulcowego do eksploatacji komercyjnej po zakończeniu badań ww. serii próbnej trójkąty hamulcowe po przeprowadzeniu prób statycznych można zabudować na wózkach wagonów towarowych, przeznaczonych do eksploatacji.

W przypadku trójkątów hamulcowych poddanych badaniom zmęczeniowym i zakończonych wynikiem pozytywnym obydwa egzemplarze należy złomować.

\section{ANALIZA STATYSTYCZNA WYNIKÓW POMIARÓW STATYCZNYCH STRZA- LEK UGIĘCIA I ODKSZTALCEŃ TRWAEYCH}

Analizę statystyczną trójkątów hamulcowych przedstawiono na podstawie badań standardowych trójkątów hamulcowych UIC/ERRI wg rys. $25 \mathrm{TNb}$ 081111-3-00 (opracowanym przez IPS „Tabor”), które zostały przeprowadzone w IPS „Tabor”. Trójkąt hamulcowy na stanowisku do badań statycznych jest przedstawiony na rys. 9 , a na stanowisku do badań zmęczeniowych na rys. 10 .

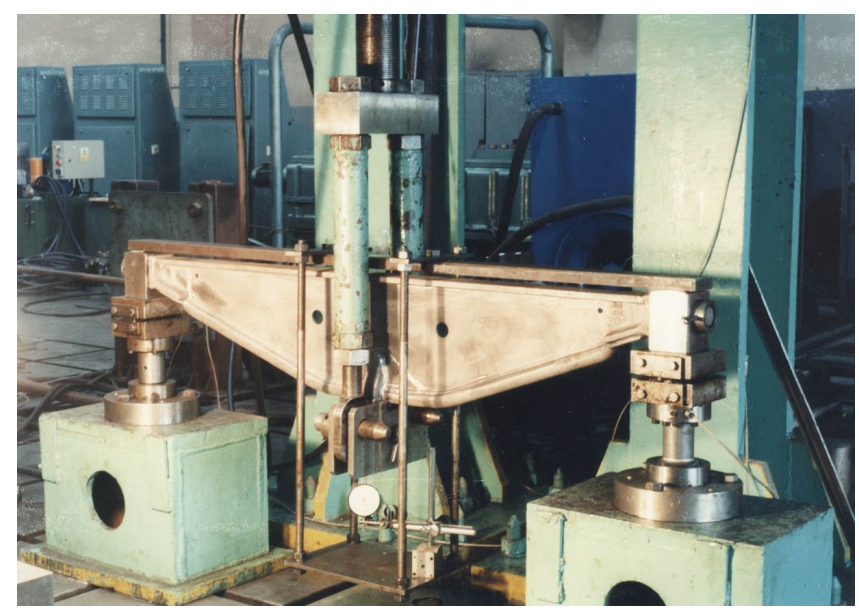

Rys. 9. Trójkąt hamulcowy do ruchu „SS” na stanowisku do badań statycznych

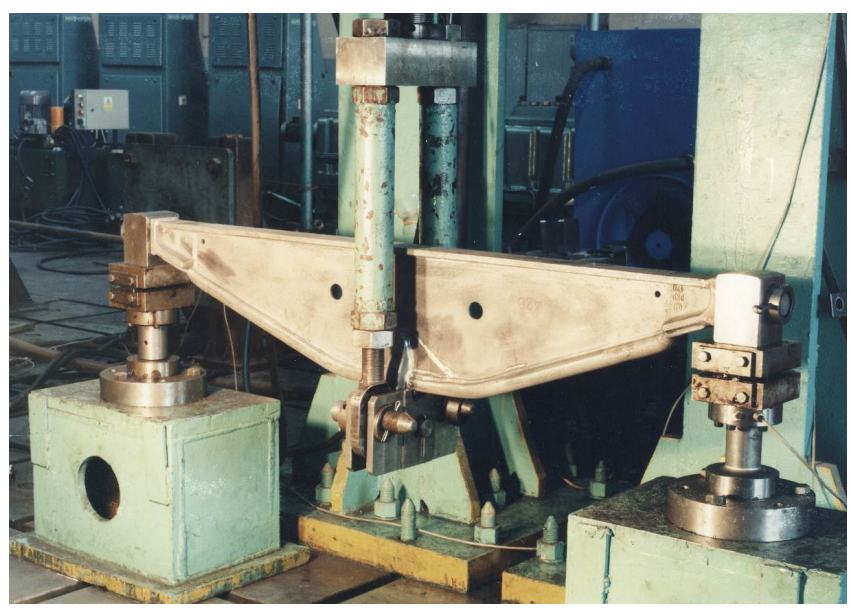

Rys. 10. Trójkąt hamulcowy do ruchu „SS” na stanowisku do badań zmęczeniowych

Wyniki pomiarów strzałek ugięcia i odkształceń trwałych przedstawiono w tabeli nr 1 .

W tabeli nr 2 przedstawiono parametry statystyczne dające pełniejszą charakterystykę otrzymanych wyników.

Odchylenie standardowe i wariancja pomierzonych strzałek ugięcia wyraża się następującymi wzorami:

$$
\begin{aligned}
\sigma & =\sqrt{\frac{\sum \mathrm{f}_{\mathrm{X}}^{2}-\mathrm{f}_{\mathrm{XSR}} \sum \mathrm{f}_{\mathrm{x}}}{\mathrm{n}-1}} \\
\mathrm{v} & =\frac{1}{\mathrm{n}-1}\left[\sum \mathrm{f}_{\mathrm{x}}^{2}-\mathrm{f}_{\mathrm{XSR}} \cdot \sum \mathrm{f}_{\mathrm{X}}\right]=\sigma^{2}
\end{aligned}
$$

We wzorach (1) i (2) n oznacza ilość badanych próbek trójkątów hamulcowych $(\mathrm{n}=8)$.

Analizując wyniki przedstawione $\mathrm{w}$ tabeli $\mathrm{nr}$ 2, odchylenie standardowe będące miarą rozproszenia pomiarowych strzałek ugięcia rośnie zasadniczo wraz ze wzrostem obciążenia trójkąta.

Ponieważ badania strzałek ugięcia dostarczyły dosyć dużą ilość wyników, analizę statystyczną można rozszerzyć, zajmując się ustaleniem stopnia powiązania pomiędzy zmiennymi otrzymanymi z doświadczenia (korelacja) oraz wyjaśnieniem istoty stosunku powiązania między zmiennymi (regresja).

Zbiór danych do ustalenia korelacji i regresji (strzałki ugięcia) jest przedstawiony w tabeli $\mathrm{nr} 3$. Niniejsze zagadnienie zostało rozwiązane dla „x” oraz „lgx” (gdzie x-obciążenie trójkątów), natomiast pierwotne wartości ,x” zostaną zakodowane przez podzielenie przez 10, aby uprościć działania.

$$
\sum^{\prime} \mathrm{x}^{2}=\sum \mathrm{k}_{\mathrm{i}} \cdot \mathrm{x}_{\mathrm{i}}^{2}-\frac{\left(\sum \mathrm{k}_{\mathrm{i}} \cdot \mathrm{x}_{\mathrm{i}}\right)^{2}}{\mathrm{~N}}
$$

gdzie:

$\mathrm{N}=\Sigma \mathrm{k}_{\mathrm{i}}$ - ilość danych 
Zestawienie ugięć i odkształceń trwałych dla wszystkich trójkątów hamulcowych przebadanych statycznie

Tabela nr 1

\begin{tabular}{|c|c|c|c|c|c|c|c|c|}
\hline \multirow{2}{*}{$\begin{array}{c}\text { Obciążenie } \\
{[\mathrm{kN}]}\end{array}$} & $\begin{array}{l}\text { Trójkąt } \\
\text { nr A1 }\end{array}$ & $\begin{array}{c}\text { Trójką̧ nr } \\
\text { A2 }\end{array}$ & \begin{tabular}{|c|} 
Trójkąt nr \\
A3 \\
\end{tabular} & $\begin{array}{c}\text { Trójkąt nr } \\
\text { A4 } \\
\end{array}$ & $\begin{array}{c}\text { Trójką̧t nr } \\
\text { A5 } \\
\end{array}$ & $\begin{array}{c}\text { Trójkąt nr } \\
\text { A6 } \\
\end{array}$ & $\begin{array}{c}\text { Trójką̧ nr } \\
\text { A7 } \\
\end{array}$ & $\begin{array}{c}\text { Trójką̧t nr } \\
\text { A8 } \\
\end{array}$ \\
\hline & \multicolumn{8}{|c|}{ Ugięcia [mm] } \\
\hline$A_{0}=10 \mathrm{kN}$ & 0 & 0 & 0 & 0 & 0 & 0 & 0 & 0 \\
\hline$B_{1=} 40 \mathrm{kN}$ & 0,45 & 0,47 & 0,43 & 0,44 & 0,44 & 0,47 & 0,49 & 0,5 \\
\hline$A_{1}=10 \mathrm{kN}$ & 0 & 0 & 0 & 0 & 0 & 0 & 0 & 0 \\
\hline$B_{2}=80 \mathrm{kN}$ & 1,06 & 1,1 & 0,99 & 1,04 & 1,05 & 1,08 & 1,11 & 1,11 \\
\hline$A_{2}=10 \mathrm{kN}$ & 0 & 0 & 0 & 0 & 0 & 0 & 0 & 0 \\
\hline$B_{3}=120 \mathrm{kN}$ & 1,68 & 1,73 & 1,54 & 1,67 & 1,65 & 1,71 & 1,73 & 1,71 \\
\hline$A_{3}=10 \mathrm{kN}$ & 0,02 & 0,05 & 0,04 & 0,04 & 0,06 & 0,05 & 0,06 & 0,05 \\
\hline$B_{4}=140 \mathrm{kN}$ & 1,99 & 2,04 & 1,83 & 1,98 & 1,95 & 2,01 & 2,05 & 2,0 \\
\hline $\mathbf{A}_{4}=10 \mathrm{kN}$ & 0,04 & 0,09 & 0,08 & 0,07 & 0,11 & 0,09 & 0,1 & 0,08 \\
\hline$B_{5}=160 \mathrm{kN}$ & 2,28 & 2,36 & 2,16 & 2,3 & 2,26 & 2,31 & 2,36 & 2,3 \\
\hline$A_{5}=10 \mathrm{kN}$ & 0,09 & 0,14 & 0,09 & 0,10 & 0,14 & 0,15 & 0,16 & 0,13 \\
\hline$B_{6}=180 \mathrm{kN}$ & 2,55 & 2,66 & 2,45 & 2,6 & 2,57 & 2,63 & 2,65 & 2,61 \\
\hline$A_{6}=10 \mathrm{kN}$ & 0,15 & 0,23 & 0,10 & 0,15 & 0,21 & 0,21 & 0,23 & 0,2 \\
\hline
\end{tabular}

Parametry statystyczne dające pełniejszą charakterystykę otrzymanych wyników z pomiarów ugięć i odkształceń trwalych

Tabela nr 2

\begin{tabular}{|c|c|c|c|c|c|}
\hline $\begin{array}{c}\text { Obciazzienie } \\
{[\mathbf{k N}]}\end{array}$ & $\boldsymbol{\Sigma} \mathbf{f}_{\mathbf{x}}$ & $\mathbf{f}_{\mathbf{X S R}}$ & $\boldsymbol{\Sigma} \mathbf{f}_{\mathbf{x}}{ }^{2}$ & $\boldsymbol{\sigma}$ & $\mathbf{v}$ \\
\hline $\mathbf{A}_{\mathbf{0}}=\mathbf{1 0} \mathbf{~ k N}$ & 0 & 0 & 0 & 0 & 0 \\
\hline $\mathbf{B}_{\mathbf{1}}=\mathbf{4 0} \mathbf{~ k N}$ & 3,69 & 0,46125 & 1,7065 & 0,025319 & 0,000641 \\
\hline $\mathbf{A}_{\mathbf{1}}=\mathbf{1 0} \mathbf{~ k N}$ & 0 & 0 & 0 & 0 & 0 \\
\hline $\mathbf{B}_{\mathbf{2}}=\mathbf{8 0} \mathbf{~ k N}$ & 8,54 & 1,0675 & 9,1284 & 0,04131759 & 0,001707 \\
\hline $\mathbf{A}_{\mathbf{2}}=\mathbf{1 0} \mathbf{~ k N}$ & 0 & 0 & 0 & 0 & 0 \\
\hline $\mathbf{B}_{\mathbf{3}}=\mathbf{1 2 0} \mathbf{~ k N}$ & 13,42 & 1,6775 & 22,5394 & 0,06250714 & 0,00390714 \\
\hline $\mathbf{A}_{\mathbf{3}}=\mathbf{1 0} \mathbf{~ k N}$ & 0,37 & 0,04625 & 0,183 & 0,0130247 & 0,00016964 \\
\hline $\mathbf{B}_{\mathbf{4}}=\mathbf{1 4 0} \mathbf{~ k N}$ & 15,85 & 1,98125 & 31,436 & 0,06250714 & 0,00475536 \\
\hline $\mathbf{A}_{\mathbf{4}}=\mathbf{1 0} \mathbf{~ k N}$ & 0,66 & 0,0825 & 0,0576 & 0,0212132 & 0,00045 \\
\hline $\mathbf{B}_{\mathbf{5}}=\mathbf{1 6 0} \mathbf{~ k N}$ & 18,33 & 2,29125 & 42,0269 & 0,06356942 & 0,00404107 \\
\hline $\mathbf{A}_{\mathbf{5}}=\mathbf{1 0} \mathbf{~ k N}$ & 1,10 & 0,125 & 0,1304 & 0,0277746 & 0,00077143 \\
\hline $\mathbf{B}_{\mathbf{6}}=\mathbf{1 8 0} \mathbf{~ k N}$ & 20,72 & 2,59 & 53,697 & 0,067823 & 0,0046 \\
\hline $\mathbf{A}_{\mathbf{6}}=\mathbf{1 0} \mathbf{~ k N}$ & 1,48 & 0,185 & 0,289 & 0,04659859 & 0,00217143 \\
\hline
\end{tabular}

gdzie:

$\sigma$ - odchylenie standardowe,

$\mathrm{v}$ - wariancja.

Po wstawieniu wartości liczbowych do wzoru (3) otrzymuje się:

$$
\begin{gathered}
\sum^{\prime} x^{2}=8\left(1^{2}+4^{2}+8^{2}+12^{2}+14^{2}+16^{2}+18^{2}\right)-\frac{8^{2}(1+4+8+12+16+18)}{56}=1917,714 \\
\sum^{\prime}(\operatorname{lgx})^{2}=\sum \mathrm{k}_{\mathrm{i}}(\operatorname{lgx})^{2}-\frac{\left(\sum \mathrm{k}_{\mathrm{i}} \cdot \mathrm{x}_{\mathrm{i}}\right)^{2}}{\mathrm{~N}}
\end{gathered}
$$

Po wstawieniu wartości liczbowych do wzoru (5) otrzymuje się:

$$
\begin{aligned}
& \sum^{\prime}(\operatorname{lgx})^{2}=8 \cdot\left(0,60205^{2}+0,90308^{2}+1,07918^{2}+1,14612^{2}+1,20411^{2}+1,25527^{2}\right) \\
& -8^{2} \frac{(0,60205+0,90308+1,07918+1,14612+1,20411+1,25527)^{2}}{56}=9,66743
\end{aligned}
$$




\begin{tabular}{|c|c|c|c|c|c|c|c|}
\hline $\mathbf{X}[\mathbf{k N}]$ & $\mathbf{1}$ & $\mathbf{4}$ & $\mathbf{8}$ & $\mathbf{1 2}$ & $\mathbf{1 4}$ & $\mathbf{1 6}$ & $\mathbf{1 8}$ \\
\hline $\lg \mathrm{x}$ & 0 & 0,060205 & 0,90308 & 1,07918 & 1,4612 & 1,20411 & 1,25527 \\
\hline 1 & 0 & 0,45 & 1,06 & 1,68 & 1,99 & 2,28 & 2,55 \\
\hline 2 & 0 & 0,47 & 1,1 & 1,73 & 2,04 & 2,36 & 2,66 \\
\hline 3 & 0 & 0,43 & 0,99 & 1,54 & 1,83 & 2,16 & 2,45 \\
\hline 4 & 0 & 0,44 & 1,04 & 1,67 & 1,98 & 2,3 & 2,6 \\
\hline 5 & 0 & 0,44 & 1,05 & 1,65 & 1,95 & 2,26 & 2,57 \\
\hline 6 & 0 & 0,47 & 1,08 & 1,71 & 2,01 & 2,31 & 2,63 \\
\hline 7 & 0 & 0,49 & 1,11 & 1,73 & 2,05 & 2,36 & 2,65 \\
\hline 8 & 0 & 0,5 & 1,11 & 1,71 & 2,0 & 2,3 & 2,61 \\
\hline$\Sigma y_{i}$ & 0 & 3,69 & 8,54 & 13,42 & 15,85 & 18,33 & 20,72 \\
\hline $\mathrm{k}_{\mathrm{i}}$ & 8 & 8 & 8 & 8 & 8 & 8 & 8 \\
\hline $\bar{y}_{\mathrm{i}}$ & 0 & 0,46125 & 1,0675 & 1,6775 & 1,98125 & 2,29125 & 2,59 \\
\hline
\end{tabular}

$$
\sum^{\prime} \mathrm{y}^{2}=\left(\sum\left(\mathrm{y}_{\mathrm{i}}\right)\right)^{2}-\frac{\left(\sum \mathrm{y}_{\mathrm{i}}\right)^{2}}{\mathrm{~N}}
$$

Po wstawieniu wartości liczbowych do wzoru (7) otrzymuje się:

$$
\begin{gathered}
\sum^{\prime} \mathrm{y}^{2}=\left(0,45^{2}+0,47^{2}+0,43^{2}+0,44^{2}+\ldots \ldots \ldots+2,61^{2}\right)-\frac{(80,55)^{2}}{56}=44,6717 \\
\sum \sum^{\prime} \mathrm{y}^{2}=\sum\left(\sum \mathrm{y}_{\mathrm{i}}^{2}-\overline{\mathrm{y}}_{\mathrm{i}} \sum \mathrm{y}_{\mathrm{i}}\right)=\sum \mathrm{y}_{\mathrm{i}}^{2}-\sum\left(\overline{\mathrm{y}}_{\mathrm{i}} \sum \mathrm{y}_{\mathrm{i}}\right)
\end{gathered}
$$

Po wstawieniu wartości liczbowych do wzoru (9) otrzymuje się:

$$
\sum \sum^{\prime} \mathrm{y}^{2}=160,5343-0,46125 \cdot 3,69+1,6775 \cdot 13,42+1,0675 \cdot 8,54+1,98125 \cdot 15,85+
$$

$$
\sum x y=\sum x y-\sum\left(k_{i} \cdot x_{i}\right) \frac{\sum y_{i}}{N}=\sum x_{i} \cdot y_{i}-\sum\left(k_{i} \cdot x_{i}\right) \frac{\sum y_{i}}{N}
$$

Po wstawieniu do wzoru (11) danych liczbowych otrzymuje się:

$$
\begin{aligned}
& \sum \mathrm{x} \cdot \mathrm{y}=1,0+4 \cdot 3,69+8 \cdot 8,54+12 \cdot 13,42+14 \cdot 15,85+16 \cdot 18,33+18 \cdot 20,72- \\
& \frac{8(1+4+8+12+14+16=18)}{56} \cdot 80,55=292,2385 \\
& \quad \sum \mathrm{ylgx}=\sum\left(\operatorname{lgx}_{\mathrm{i}} \cdot \sum \mathrm{y}_{\mathrm{i}}\right)-\sum\left(\mathrm{k}_{\mathrm{i}} \cdot \log \mathrm{x}_{\mathrm{i}}\right) \cdot \frac{\sum \mathrm{y}_{\mathrm{i}}}{\mathrm{N}}
\end{aligned}
$$

Po wstawieniu wartości liczbowych do wzoru (12) otrzymuje się:

$$
\begin{aligned}
& \sum^{\prime} y \cdot \lg x=0,60205 \cdot 3,69+0,90308 \cdot 8,54+1,07918 \cdot 13,42+1,4612 \cdot 15,85+1,20411 \cdot 18,33+ \\
& +1,25527 \cdot 20,72-\frac{8(0,60205+0,90308+1,07918+1,14612+1,20411+1,25527)}{56} \cdot 80,55 \\
& =19,4359
\end{aligned}
$$

Dla prostej $\mathrm{y}=\mathrm{x}$ :

$$
\sum \mathrm{c}^{2}=\frac{\left(\sum \mathrm{x} \cdot \mathrm{y}\right)^{2}}{\sum \mathrm{x}^{2}}
$$


Po wstawieniu wartości liczbowych, wyliczonych na podstawie zależności (3) oraz (11) do wzoru (13) otrzymuje się:

$$
\sum \mathrm{c}^{2}=\frac{(292,2385)^{2}}{1917,714}=44,5339
$$

Dla prostej $\mathrm{y}=\operatorname{lgx}$ :

$$
\sum \mathrm{c}^{2}=\frac{\left(\sum^{\prime} \mathrm{ylgx}\right)^{2}}{\sum^{\prime}(\operatorname{lgx})^{2}}
$$

Po wstawieniu wartości liczbowych, wyliczonych poprzez podstawienie zależności (6) i (12) do wzoru (14) otrzymuje się:

$$
\sum \mathrm{c}^{2}=\frac{(19,4359)^{2}}{9,66743}=39,07493
$$

Współczynniki nachylenia prostych wyznacza się z wzorów:

$$
\text { by : } x=\frac{\sum x y}{\sum x^{2}}=\frac{292,2385}{1917,714}=0,15238
$$

oraz

$$
\text { by : } x=\frac{\sum{ }^{\prime} \lg x}{\sum{ }^{\prime}(\lg x)^{2}}=\frac{19,4359}{9,66743}=2,010451
$$

Wyniki analizy wariancyjnej zebrano w tabeli nr 4.

Zestawienie parametrów analizy wariancyjnej

Tabela nr 4

\begin{tabular}{|c|c|c|c|c|}
\hline L.p. & $\begin{array}{c}\text { Określenie } \\
\text { parametru }\end{array}$ & Suma kwadratów & $\begin{array}{c}\text { Ilość } \\
\text { stopni } \\
\text { swobody }\end{array}$ & $\begin{array}{c}\text { Średni } \\
\text { kwadrat }\end{array}$ \\
\hline 1 & Prosta y:x $\Sigma^{\prime} \mathrm{c}^{2}$ & 44,5339 & 1 & 44,5339 \\
\hline 2. & $\begin{array}{c}\text { Prosta y:logx } \\
\Sigma^{\prime} \mathrm{c}^{2}\end{array}$ & 39,07493 & 1 & 39,07493 \\
\hline 3. & $\begin{array}{c}\text { Restka od } \\
\text { prostej } \\
\text { y: } \sum^{\prime} y_{x}^{2}\end{array}$ & 0,0002375 & 5 & 0,0000475 \\
\hline 4. & $\begin{array}{c}\text { Resztka od } \\
\text { prostej y:logx } \\
\sum \hat{y}^{\prime} \hat{y}_{\operatorname{logx}}^{2}\end{array}$ & 5,4592075 & 5 & 1,0918415 \\
\hline 5. & Błąd $\Sigma \Sigma^{\prime} \mathrm{y}_{\mathrm{i}}^{2}$ & 0,1375625 & 49 & 0,0002807 \\
\hline 6. & Ogółem $\Sigma^{\prime} \mathrm{y}_{\mathrm{i}}{ }^{2}$ & 44,6717 & 55 & 0,8122127 \\
\hline
\end{tabular}

Resztkę od prostej korelacji y:x wyznacza się ze wzoru:

$$
\sum \hat{y}_{\mathrm{x}}{ }^{2}=\sum \mathrm{y}^{2}-\sum \sum \mathrm{y}^{2}-\sum^{\prime} \mathrm{c}^{2}
$$

Po wstawieniu wartości liczbowych do wzoru (18) otrzymuje się:

$$
\sum^{\prime} \hat{y}_{x}{ }^{2}=44,6717-0,1375625-44,5939=0,0002375
$$

Resztka od prostej korelacji y:lgx wyznacza się ze wzoru:

$$
\sum \hat{y}^{\prime g x^{2}}=\sum{ }^{\prime} \hat{y}^{2}-\sum \sum y^{2}-\sum{ }^{\prime} c^{2}
$$

Po wstawieniu wartości liczbowych do wzoru (19) otrzymuje się:

$\sum \hat{y}_{\lg x^{2}}=44,6717-0,1375625-39,07493=5,452075$

Ponieważ resztka od prostej y:lgx $\sum \hat{y}_{\lg x^{2}}$ jest większa od resztki $\sum y_{x^{2}}$ jest większa od resztki $\sum \hat{y}_{x^{2}} \mathrm{y}: \mathrm{x}$ to korelacja prostoliniowa jest o wiele istotniejsza. Korelacja zmiennych jest zachowana pomimo błędów. wynosi:

Wyraz wolny prostej korelacji strzałek ugięcia

$$
\begin{gathered}
\mathrm{a}=\overline{\mathrm{y}}-\mathrm{b} \overline{\mathrm{x}} \\
\mathrm{a}=\frac{\sum \mathrm{y}_{\mathrm{i}}}{\mathrm{N}}-\mathrm{b} \cdot \overline{\mathrm{x}} \\
\mathrm{a}=\frac{80,55}{56}-0,15238 \cdot 10,428571=-0,1507128
\end{gathered}
$$

Ostateczne równanie prostej korelacji:

$$
\mathrm{Y}=0,15238-0,1507128
$$

Współczynnik korelacji określono ze wzoru:

$$
r=\frac{\sum^{\prime} \mathrm{xy}}{\left(\sum^{\prime} \mathrm{x}^{2} \cdot \sum^{\prime} \mathrm{y}^{2}\right)^{0,5}}
$$

Po wstawieniu wartości liczbowych do wzoru (23) otrzymuje się:

$$
r=\frac{292,2385}{\sqrt{1917,714 \cdot 44,6717}}=0,99845678
$$

Współczynnik korelacji o wartości $0,99845678(\approx 1)$ pozwala na stwierdzenie, że próby potwierdziły duże powiązanie zmiennych.

Granice ufności współczynnika nachylenia prostej najmniejszych kwadratów określono wg wzorów:

gdzie:

$$
\mathrm{s}^{2}\left(\hat{\mathrm{y}}_{\mathrm{i}}\right)=\frac{\left(1-\mathrm{r}^{2}\right) \sum \mathrm{y}^{2}}{\mathrm{~N}-2}
$$

$\mathrm{s}^{2}\left(\mathrm{y}_{\mathrm{i}}\right)$ - wariancja dowolnego oszacowania przeciętnej wartości $\mathrm{y}_{\mathrm{i}}$,

N-2 - ilość stopni swobody, służące do określenia odchylenia standardowego.

Po wstawieniu wartości liczbowych do wzoru (24) otrzymuje się:

$$
\begin{gathered}
\mathrm{s}^{2}\left(\hat{\mathrm{y}}_{\mathrm{i}}\right)=\frac{\left(1-0,99845678{ }^{2}\right) \sum 44,6717^{2}}{54}=0,002551298 \\
\mathrm{~s}^{2}(\mathrm{~b})=\frac{\mathrm{s}^{2}(\hat{\mathrm{y} i})}{\sum^{\prime} \mathrm{x}^{2}}=\frac{0,002551298}{1917,714}=0,0000133 \\
\mathrm{~s}(\mathrm{~b})=0,001153423=1,1534 \cdot 10^{-3}
\end{gathered}
$$

gdzie:

$\mathrm{s}^{2}(\mathrm{~b})$ - wariancja współczynnika nachylenia prostej. 


$$
\begin{aligned}
\mathrm{s}^{2}(\overline{\mathrm{y}})=\frac{\mathrm{s}^{2}\left(\hat{\mathrm{y}}_{\mathrm{i}}\right)}{\mathrm{N}} & =\frac{0,002551298}{56}=0,000045558 \\
s(\bar{y}) & =0,006749732
\end{aligned}
$$

Stosując test „t-Studenta” dla 95\% przedziału ufności:

$$
\mathrm{t}(0,05 \mathrm{~N}=54)=2,00
$$

95\% przedział ufności

$\bar{y}=\frac{80,55}{56}=1,438 \pm 2 \cdot 0,006749732=1,4245 \div 1,451499 \mathrm{~mm}$ $95 \%$ przedział ufności dla b:

$0,15238 \pm 2 \cdot 0,15238 \cdot 0,0011534=0,15238 \pm 0,0023068$.

Wykresy odpowiednich prostych przedstawiono na rys.11.

Analogiczną analizę przeprowadzono dla ugięć trwałych. Zbiór otrzymanych danych dla potrzeb dalszej analizy przedstawiono w tabeli $\mathrm{nr} 5$.

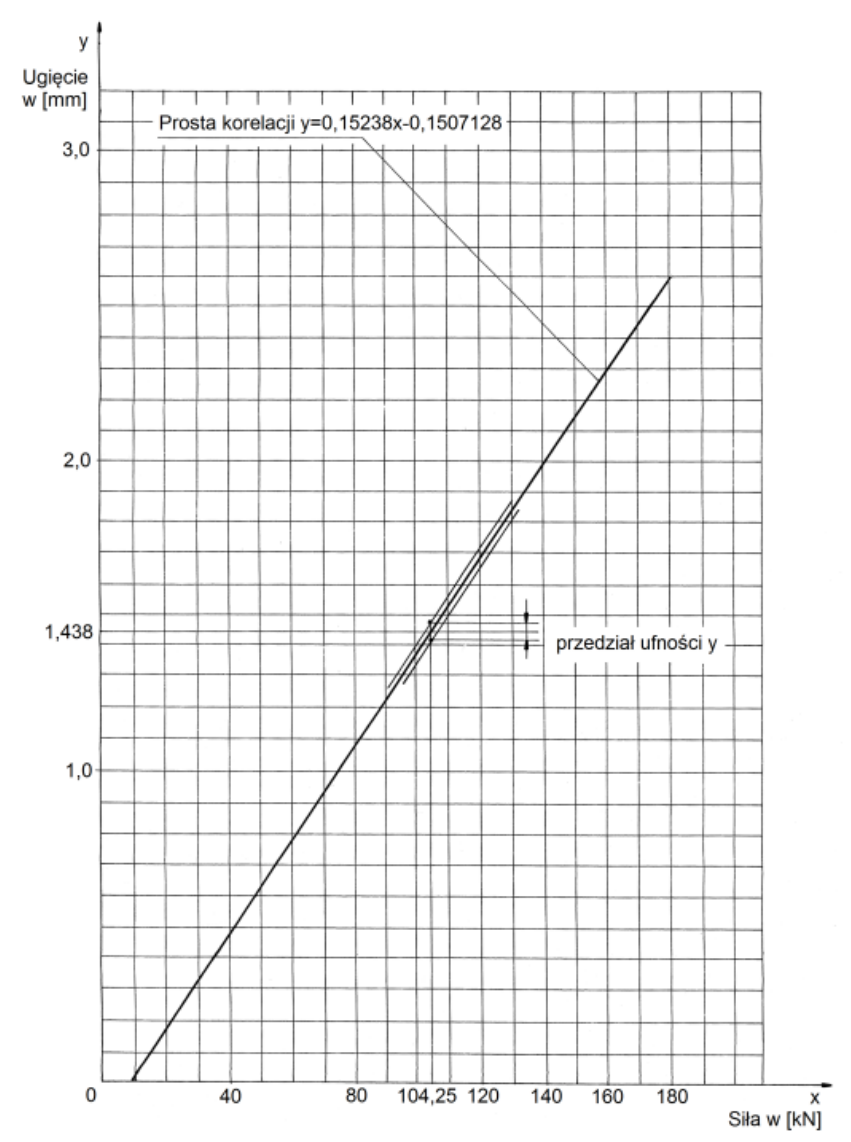

Rys.11. Prosta korelacji ugięć trójkąta hamulcowego w zależności od siły obciążającej

Zbiór danych do ustalenia korelacji i regresji (odkształcenie trwale)

Tabela nr 5

\begin{tabular}{|c|l|c|c|c|c|c|c|}
\hline $\mathbf{x ~ k N ]}$ & $\mathbf{1}$ & $\mathbf{4}$ & $\mathbf{8}$ & $\mathbf{1 2}$ & $\mathbf{1 4}$ & $\mathbf{1 6}$ & $\mathbf{1 8}$ \\
\hline $\lg \mathbf{n}$ & 0 & 0,60205 & 0,90308 & 1,07918 & 1,14612 & 1,20411 & 1,25527 \\
\hline 1 & 0 & 0 & 0 & 0,02 & 0,04 & 0,09 & 0,15 \\
\hline 2 & 0 & 0 & 0 & 0,05 & 0,09 & 0,14 & 0,23 \\
\hline 3 & 0 & 0 & 0 & 0,04 & 0,08 & 0,09 & 0,10 \\
\hline 4 & 0 & 0 & 0 & 0,04 & 0,07 & 0,10 & 0,15 \\
\hline 5 & 0 & 0 & 0 & 0,06 & 0,11 & 0,14 & 0,21 \\
\hline 6 & 0 & 0 & 0 & 0,05 & 0,09 & 0,15 & 0,21 \\
\hline 7 & 0 & 0 & 0 & 0,06 & 0,10 & 0,16 & 0,23 \\
\hline 8 & 0 & 0 & 0 & 0,05 & 0,08 & 0,13 & 0,20 \\
\hline$\Sigma \mathrm{y}_{\mathrm{i}}$ & 0 & 0 & 0 & 0,37 & 0,66 & 1,00 & 1,48 \\
\hline $\mathrm{k}_{\mathrm{i}}$ & 8 & 8 & 8 & 8 & 8 & 8 & 8 \\
\hline $\bar{y}_{i}$ & 0 & 0 & 0 & 0,04625 & 0,0825 & 0,125 & 0,185 \\
\hline
\end{tabular}

$$
\sum^{\prime} x^{2}=8 \cdot\left(1^{2}+4^{2}+8^{2}+12^{2}+16^{2}+18^{2}\right)-\frac{8^{2}(1+4+8+12+14+16+18)^{2}}{56}=1917,714
$$$$
\sum^{\prime}(\lg x)^{2}=8 \cdot\left(0,60205^{2}+0,90308^{2}+1,07918^{2}+1,14612^{2}+1,20411^{2}+1,25527^{2}\right)-
$$$$
\frac{8^{2}\left(0,60205^{2}+090308^{2}+1,07918^{2}+1,14612^{2}+1,20411^{2}+1,25527^{2}\right)}{56}
$$

$\sum^{\prime}(\lg x)^{2}=8 \cdot\left(0,60205^{2}+0,90308^{2}+1,07918+1,14612+1,20411+1,25527\right)-$

$\frac{8^{2}(0,60205+0,090308+1,07918+1,14612+1,20411+1,25527)^{2}}{56}=9,66743$ 
$\sum y^{2}=\left(0,02^{2}+0,04^{2}+\ldots \ldots \ldots \ldots \ldots \ldots+0,2^{2}\right)-\frac{3,51^{2}}{56}=0,27529$

$\sum \sum y^{2}=0,4953-(0,37 \cdot 0,04625+0,66 \cdot 0,0825+1,0 \cdot 0,125+1,48 \cdot 0,185)=0,0249375$

$\sum^{\prime} \mathrm{xy}=\left(12 \cdot 0,37+14 \cdot 0,66+16 \cdot 1+18 \cdot 1,48-\frac{8 \cdot(1+4+8+12+14+16+18)}{56} \cdot 3,51\right)$

$=19,1571429$

$\sum^{\prime}(\operatorname{lgx})^{2}=1,07918 \cdot 0,37+1,14612 \cdot 0,66+1,20411 \cdot 1,00+1,25527 \cdot 1,48-$

$-\frac{8(0,60205+0,90308+1,07918+1,20411+1,20411+1,25527)}{56}=9,66743$

$\sum y^{2}=\left(0,02^{2}+0,04^{2}+\ldots \ldots \ldots \ldots \ldots \ldots \ldots \ldots+0,2^{2}\right)-\frac{3,51^{2}}{56}=0,275298214$

$\sum \sum y^{\prime}=0,4953-(0,37 \cdot 0,04625+0,66 \cdot 0,0825+1,0 \cdot 0,125+1,48 \cdot 0,185)=0,0249375$

$\sum x y=\left(12 \cdot 0,37+14 \cdot 0,66+16 \cdot 1,00+18 \cdot 1,48-\frac{8(1+4+8+12+14+16+18)}{56} \cdot 3,51\right)$

$=19,1571429$

$\sum y \lg x=1,07918 \cdot 0,37+1,14612 \cdot 0,66+1,20411 \cdot 1,0+1,25527 \cdot 1,48-$

$\frac{8 \cdot(0,60205+0,90308+0,7918+1,14612+1,225527 \cdot 1,48)}{56} \cdot 3,51=1,113897814$

$\sum^{\prime} \mathrm{c}^{2}($ dla prostej $\mathrm{y}: \mathrm{x})=\frac{\left(\sum \mathrm{y} \cdot \lg \mathrm{x}\right)}{\sum{ }^{\prime}(\lg \mathrm{x})^{2}}=\frac{(1,113897814)^{2}}{9,66743}=0,1283452$

Współczynniki nachylenia prostych wynoszą odpowiednio:

$\mathrm{b}_{\mathrm{y}: \mathrm{x}}=\frac{\sum^{\prime} \mathrm{x} \cdot \mathrm{y}}{\sum \mathrm{x}^{2}}=\frac{19,71571429}{1917,714}=0,010280841$

$\mathrm{b}_{\mathrm{y} \log \mathrm{x}}=\frac{\sum^{\prime} \mathrm{ylg}^{\prime} \mathrm{l}}{\sum^{\prime}(\lg \mathrm{lg})^{2}}=\frac{1,113897814}{9,66743}=0,115221709$

Resztka od prostej korelacji y:x: $\sum \hat{y}^{2}=0,275298214-0,0249375-0,20269414$

Resztka od prostej korelacji y:logx:

$\sum \hat{y}_{\log x^{2}}=0,275298214-0,0249375-0,12834521=0,122015504$

Wyniki analizy wariancyjnej zebrano w tabeli nr 6.

Zestawienie wyników analizy wariancyjnej

Tabela 6

\begin{tabular}{|c|c|c|c|c|}
\hline L.p. & Określenie parametru & Suma kwadratów & $\begin{array}{c}\text { Ilość stopni } \\
\text { swobody }\end{array}$ & Średni kwadrat \\
\hline 1 & Prosta y: $\Sigma^{\prime} \mathrm{c}^{2}$ & 0,20269414 & 1 & 0,20269414 \\
\hline 2. & Prosta y:logx $\Sigma^{\prime} \mathrm{c}^{2}$ & 0,12834521 & 1 & 0,12834521 \\
\hline 3. & Resztka od prostej y:x $\Sigma^{\prime} \hat{y}_{x}{ }^{2}$ & 0,047666574 & 5 & 0,009533314 \\
\hline 4. & $\begin{array}{c}\text { Resztka od prostej y:logx } \\
\Sigma \hat{y} \log _{x^{2}}\end{array}$ & 0,122015504 & 5 & 0,0244031 \\
\hline 5. & Błąd $\Sigma \Sigma^{\prime} y^{2}$ & 0,0249375 & 49 & 0,0002807 \\
\hline 6. & Ogółem $\Sigma^{\prime} y^{2}$ & 0,275298214 & 55 & \\
\hline
\end{tabular}


Z porównania ,resztek” $\sum \hat{y}^{2}$ od prostych y:x oraz y: $\log x$ z błędem $\sum \sum y^{2}$ wynika, że najistotniejsza jest korelacja prostoliniowa, która wybrano do dalszej analizy:

Wyraz wolny od prostej korelacji ugięć trwałych wynosi:

$$
a=\bar{y}-b \cdot \bar{x}
$$

Po podstawieniu danych liczbowych otrzymuje się:

$$
a=\frac{\sum y_{i}}{56}-b \cdot \frac{73}{7}=\frac{3,51}{56}-0,010280941 \cdot 10,428571=-0,044535913
$$

Ostateczna postać prostej korelacji przedstawia się następująco:

$$
y=0,0100280841 \cdot x-0,044535913
$$

Współczynnik korelacji określono ze wzoru (23):

$$
r=\frac{19,71571429}{\sqrt{1917,714 \cdot 0,275298214}}=0,8580
$$

Korzystając z tablicy 8.2 [2] można wyciągnąć wniosek, że korelacja istnieje (dla $\mathrm{N}=50 \mathrm{r}=0,4423$ ), a więc otrzymany współczynnik „r” jest większy na poziomie prawdopodobieństwa 0,001 ).

Następnie ustalono granice ufności współczynnika nachylenia prostej regresji i prostej najmniejszych kwadratów:

$$
\begin{gathered}
\mathrm{s}^{2}\left(\hat{\mathrm{y}}_{\mathrm{i}}\right)=\frac{\left(1-0,8580^{2}\right) \cdot 0,2752988214}{54}=0,001345056 \\
\mathrm{~s}^{2}(\mathrm{~b})=\frac{0,001345056}{1917,45}=7,014870211 \cdot 10^{-7} \\
\mathrm{~s}(\mathrm{~b})=0,000837548=8,37548 \cdot 10^{-4} \\
\mathrm{~s}^{2}(\mathrm{y})=\frac{\mathrm{s}^{2}\left(\mathrm{y}_{\mathrm{i}}\right)}{\mathrm{N}}=\frac{0,001345056}{56}=0,000014956
\end{gathered}
$$

Stosując test ,t-Studenta” określane $t_{\alpha}$ na $\mathrm{t}_{0,005, \mathrm{~N}=54}=2,00$ (tablica 6.1 źródła [2]).

W związku z powyższym:

\section{5\% przedziału ufności:}

$$
\begin{aligned}
& \bar{y}=\frac{\sum y_{i}}{N} \pm 2,00 \cdot 0,003867327 \\
& \bar{y}=0,062678571 \pm 0,07734654
\end{aligned}
$$

95\% przedział ufności: $\mathrm{b}=0,010280841 \pm 0,07734654$

$$
\begin{aligned}
& b=, 010280841 \pm 2 \cdot 8,37548 \cdot 10^{-} \\
& b=0,010280841 \pm 0,001675096 \\
& b=, 008505745 \div 0,0011955937
\end{aligned}
$$

Wykres prostej korelacji jest przedstawiony na rys.12.

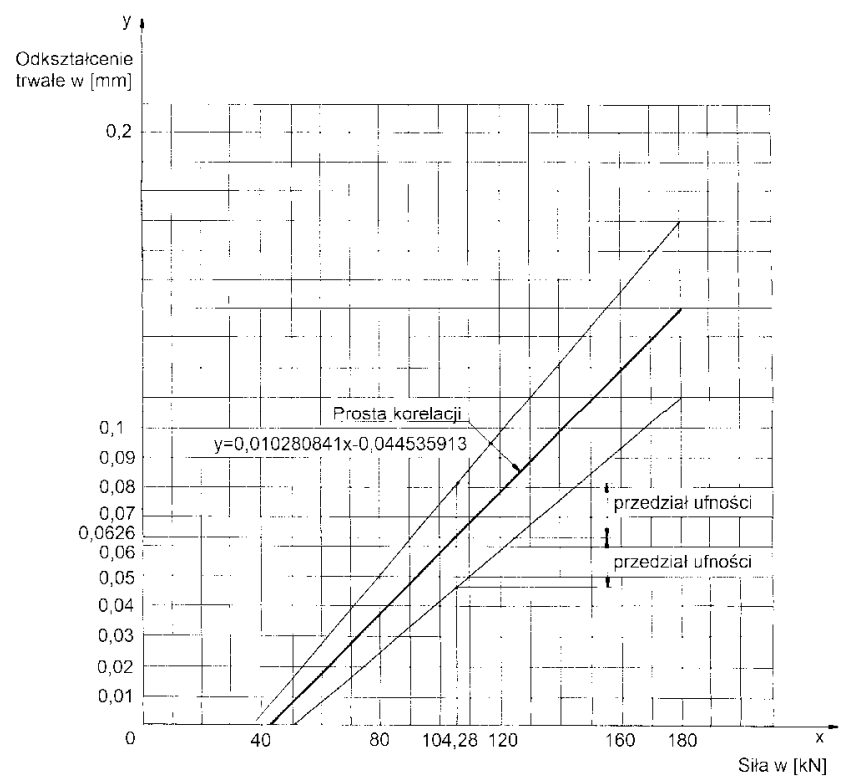

Rys. 12. Prosta korelacji ugięć trwałych trójkąta hamulcowego w zależności od siły

\section{STRZALKI UGIĘCIA WYZNACZANE METO- DĄ STATYSTYCZNĄ}

Jak wynika z przeprowadzonej analizy statystycznej, istnieje korelacja prostoliniowa pomiędzy strzałką ugięcia i obciążenia. Bardzo wysoki współczynnik korelacji r=0,9984 potwierdza duże powiązanie zmiennych. Korelacja ta jest na pewno lepsza od korelacji logarytmicznej.

Strzałki ugięcia trójkątów hamulcowych można wyznaczyć metodą statystyczną. Wartość odchylenia standardowego spodziewanej wartości strzałek ugięcia dla trójkątów hamulcowych obciążonych odpowiednio siłą $P_{1}=120 \mathrm{kN}$ oraz siłą $\mathrm{P}_{2}=180 \mathrm{kN}$ wynosi odpowiednio:

$$
s^{2}\left(\hat{y}_{i}\right)=s^{2}(\hat{y})\left[1+\frac{1}{N}+\frac{\left(\bar{x}-x_{i}\right)}{\sum x_{i}^{2}}\right]
$$

Po wstawieniu danych liczbowych otrzymuje się:

$$
\mathrm{s}^{2}\left(\hat{\mathrm{y}}_{\mathrm{i}}\right)=0,002551298\left[1+\frac{1}{56}+\frac{(12-10,4285)}{1917,714}\right]
$$

$$
s\left(\hat{y}_{i}\right)=0,050991396
$$

Ponieważ dla siły $\mathrm{P}_{1}=120 \mathrm{kN}, \hat{\mathrm{y}}_{\mathrm{i}}=1,6778472 \mathrm{~mm}$ to spodziewana wartość strzałki ugięcia przy 99\% przedziale ufności wynosi:

$$
1,677847 \pm 2,66 \cdot 0,050991396=1,677847 \pm 0,135637
$$

czyli: $1,5422102 \div 1,813484$, a po zaokragleniu do dokładności pomiarowej 1,54 $\div 1,81 \mathrm{~mm}$.

Ponieważ dla $\mathrm{P}_{2}=180 \mathrm{kN}, \hat{\mathrm{y}}_{\mathrm{i}}=2,5921272 \mathrm{~mm}$, to spodziewana wartość strzałki ugięcia przy $99 \%$ przedziale ufności wynosi: 


$$
\mathrm{s}^{2}\left(\hat{\mathrm{y}}_{\mathrm{i}}\right)=0,002551298\left[1+\frac{1}{56}+\frac{(18-10,4285)}{1917,714}\right]
$$

a zatem:

$$
s\left(\hat{y}_{i}\right)=0,051702177
$$

$2,5921272 \pm 2,66 \cdot 0,051702177=2,5921272 \pm 0,1375277$

$9 \mathrm{~mm}$, a po zaokrągleniu do dokładności pomiarowej:

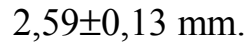

Wartości spodziewanych strzałek ugięcia trójkątów hamulcowych oszacowano na podstawie rozkładu „t-Studenta”. Rozkład ten nie jest rozkładem normalnym, chociaż w pewnych warunkach zbliża się do rozkładu normalnego. Jest to odrębna funkcja matematyczna, zależna od liczby pomiarów wykorzystanych do obliczenia odchylenia standardowego „,". Jeśli n jest liczbą elementów w próbkach, wahającą się od 2 do ? , to t ma różny rozkład dla każdej wartości n, zbieżny do rozkładu normalnego gdy $\mathrm{n}$ dąży do nieskończoności.

Spodziewana strzałka ugięcia dla siły $\mathrm{P}_{2}=180$ $\mathrm{kN}$ zawiera się w granicach $2,4545 \div 2,72965 \mathrm{~mm}$, a po zaokrągleniu do dokładności pomiarowej $2,45 \div 2,72$ $\mathrm{mm}$.

Wartość t obowiązuje dla $\mathrm{N}=56-2=54$ stopni swobody przy prawdopodobieństwie 0,01 (tablica 6.1) [2].

Odpowiednie wyniki zebrano w tabeli 7 dla prawdopodobieństwa $90 \%, 95 \%, 98 \%$ oraz $99,9 \%$ dla $\mathrm{N}=56$ stopni swobody (dla obciążeń trójkąta hamulcowego $\mathrm{P}_{1}=120 \mathrm{kN}$ i $\mathrm{P}_{2}=120 \mathrm{kN}$ ). Wyrażenie $t s(\bar{x})$ można uznać za ocenianie dokładności pomiaru $\bar{x}$. Jeśli np. 90\%, 95\%, 98\% podobnych pomiarów $\bar{x}$ wypadnie w przedziale $\bar{x} \pm t s(\bar{x})$, gdzie $\mathrm{t}$ jest wzięte na podstawie istotności odpowiednio $0,1,0,05$ oraz 0,02 . Jeśli oznaczy się granice dokładności, zwane zazwyczaj dokładnością symbolem „l” to wówczas otrzymuje się zależność:

$$
1_{0,95 ; \overline{\mathrm{x}}}= \pm \mathrm{t}_{0,05 ; \mathrm{N}-2} \cdot \mathrm{s}(\mathrm{x})
$$

\section{WNIOSKI}

Przedstawiona powyżej metoda badań prostej regresji i korelacji pomiędzy odpowiednio obciążeniami i ugięciami może służyć do oceny powtarzalno- ści stosowanej technologii przez producenta. Jeśli spodziewana strzałka ugięcia dla obciążeń, stosowanych $w$ badaniach tzn. $\mathrm{P}_{1}=120 \mathrm{kN}$ oraz $\mathrm{P}_{2}=180 \mathrm{kN}$ dla trójkątów przeznaczonych dla ruchu „SS" oraz $\mathrm{P}_{1}=60$ $\mathrm{kN}$ oraz $\mathrm{P}_{2}=90 \mathrm{kN}$ cechuje się małym stopniem rozproszenia, można wnioskować, że przyjęta technologia wytwarzania jest prawidłowa. Szczególnie jest to istotne w przypadku ultralekkich konstrukcji trójkątów hamulcowych, które mają strzałki ugięcia bardzo zbliżone do wyznaczonych kryteriów. Warto zaznaczyć, że kryterium dopuszczalnej strzałki ugięcia jest bardzo ważne z uwagi na ograniczenie skoku cylindra hamulcowego oraz zdolności regulacyjnych nastawiaczy skoku klocków hamulcowych. Aby skok cylindra w klasycznych układach dźwigniowych był wystarczający należy uwzględnić wiele czynników jak zużycie wstawek klocków hamulcowych, zużycie sworzni i tulejek w układach dźwigniowych, zużycie powierzchni tocznej koła, sprężyste ugięcie elementów układu dźwigniowego.

\section{LITERATURA}

1. Sobaś M.: Trójkaty hamulcowe nowej generacji dla wagonów towarowych. Pojazdy Szynowe nr 3/2010.

2. Volk W.: Statystyka stosowana dla inżynierów. $W N-T$ Warszawa. 1965.

3. Karta UIC 543: Hamulec. Przepisy dotyczace wyposażenia wagonów. 13-te wydanie ze stycznia i kwietnia 2007.

4. Karta UIC 832: Warunki techniczne dostawy wstawek klocków hamulcowych z żeliwa fosforowego dla pojazdów trakcyjnych $i$ wagonów.

5. Karta UIC 833: Warunki techniczne na dostawę trójkqtów hamulcowych. 3-cie wydanie z lutego 2004.

6. PN-91/K-88176: Wagony towarowe. Trójkaty hamulcowe.

7. Zagadnienie UIC 6-110. Zwalczanie hałasu. Zabudowa wstawek z tworzyw kompozytowych. Wytyczne zastosowania $V$-BKS (LL))-9 te wydanie.

8. Zastosowanie wstawek klocków hamulcowych $z$ tworzyw sztucznych $(V-B K S)$. Katalog Uszkodzeń. 2-gie wydanie z 14.10.2009.

9. Przepisy TSI: Decyzja komisji dotyczqca specyfikacji interoperacyjności odnoszqcej się do podsystemu ,tabor kolejowy - wagony towarowe" transeuropejskiego systemu kolei konwencjonalnych z dnia 26 lipca 2006 r. Dziennik Urzędowy Unii Europejskiej

Zestawienie spodziewanych strzalek ugięcia na podstawie rozkladu „t-Studenta”

Tabela 7

\begin{tabular}{|c|c|c|c|c|c|c|}
\hline \multirow{2}{*}{ Obciążenie i ugięcie } & \multicolumn{5}{|c|}{ Poziom prawdopodobieństwa } \\
\cline { 3 - 7 } & $\mathbf{0 , 9 0}$ & $\mathbf{0 , 9 5}$ & $\mathbf{0 , 9 8}$ & $\mathbf{0 , 9 9}$ & $\mathbf{0 , 9 9 9}$ \\
\hline \multicolumn{2}{|c|}{$\mathbf{t}_{\alpha}$} & $\alpha=0,1$ & $\alpha=0,05$ & $\alpha=0,02$ & $\alpha=0,01$ & $\alpha=0,001$ \\
\cline { 3 - 7 } & 1,671 & 2,000 & 2,390 & 2,660 & 3,450 \\
\hline $\begin{array}{c}\mathbf{P}_{\mathbf{1}}=\mathbf{1 2 0} \\
\mathbf{k N}\end{array}$ & $\begin{array}{c}\text { Ugięcie } \\
{[\mathbf{m m}]}\end{array}$ & $1,67 \pm 0,08^{1)}$ & $1,67 \pm 0,10$ & $1,67 \pm 0,12$ & $1,67 \pm 0,13$ & $1,67 \pm 0,17$ \\
\hline $\begin{array}{c}\mathbf{P}_{\mathbf{1}}=\mathbf{1 8 0} \\
\mathbf{k N}\end{array}$ & $\begin{array}{c}\text { Ugięcie } \\
{[\mathbf{m m}]}\end{array}$ & $2,59 \pm 0,08^{1)}$ & $2,59 \pm 0,10$ & $2,59 \pm 0,12$ & $2,59 \pm 0,13$ & $2,59 \pm 0,17$ \\
\hline
\end{tabular}

${ }^{1)}$ wartości odchylenia strzałki ugięcia są równe dla siły obciążającej $\mathrm{P}_{1}=120 \mathrm{kN}$ oraz $\mathrm{P}_{2}=180 \mathrm{kN}$, ale dopiero po zaokrągleniu do drugiego miejsca po przecinku 